\title{
Attitudinal Differences Towards Instructional Supervision: A Study of Teacher Beliefs and Supervisory Behaviour in Malaysia
}

\author{
Sailesh Sharma ${ }^{1} \&$ Saleh Al-Sinawai ${ }^{2}$ \\ ${ }^{1}$ School of Education, Apeejay Stya University, Gurgaon, India \\ ${ }^{2}$ A'Sharqiyah University, Oman \\ Correspondence: Sailesh Sharma, School of Education, Apeejay Stya University, Gurgaon, Haryana, India.
}

\author{
Received: April 6, 2019 \\ Accepted: May 19, 2019 Online Published: July 29, 2019 \\ doi:10.5539/ies.v12n8p106 \\ URL: https://doi.org/10.5539/ies.v12n8p106
}

\begin{abstract}
The purpose of this study is to investigate the supervisory beliefs of the teachers. It examines a number of distinct aspects of teachers' beliefs in regard to supervision: position, supervisor's experience, length of service, level of education, age and gender. The respondents of this study were seventy teachers from one of the secondary schools in Malaysia. Data was collected through the use of the instrument devised by Glickman and Tomashiro (1980) "Determining one's Beliefs regarding Teacher Supervision". Cross tabulation, Pearson Chi Square, and Cramer's V test were used to analyse the data. The findings suggested that supervisory beliefs are independent of demographic variables and directive behaviours are among the most preferred behaviours.
\end{abstract}

Keywords: instructional supervision, supervisory beliefs, supervisory behaviors, educational leadership

\section{Introduction}

The Professional Circular No. 3/1987 by the Ministry of Education of the Government of Malaysia contained the following statement:

"Duties and functions of the Principal/Headmaster as professional leaders, managers and administrators today are diverse, as the leader of professionals in the school, the primary responsibility of a Principal/Headmaster is to ensure the successful implementation of the curriculum at the school. The implementation of curriculum through the teaching-learning activities carried out by the teachers and the effectiveness of the curriculum in schools needs close systematic supervision from the Principal/Headmaster of the school. The supervision of teaching and learning for teachers in the classroom should be a priority in the list of duties and responsibilities of the Principal/Headmaster. The Principal/Headmaster should understand that supervision duty is of utmost important."

Any principal has multiple roles to play in their school. As an instructional leader s/he has to carry out both the duty of a manager and a leader. As a manager s/he has a duty to make sure everything is done right while as a leader $\mathrm{s} / \mathrm{he}$ has to be a visionary and inspire the people under him. This includes the ability to intelligently manage, direct, organize, steer and thrust the members of the organization (school) towards achieving institutional and personal goals. In this context, one of the duties of an instructional leader is supervision.

\subsection{Supervision Concept}

Supervision can be defined as overseeing someone doing their work with the intention to improve them in their task. Furthermore, it can be said that supervision consists of overseeing an individual's work, and at the same time attempting to improve and extend the supervisee's levels of professionalism. As a subject of academic discourse, 'supervision in education', or 'instructional supervision', has its origins in the late $19^{\text {th }}$ century in American education, during the height of the industrial revolution when schools became more organized and networked. During those early years, supervision was simply a function that 'superintendents' performed to oversee schools more efficiently (Sullivan, 2000). At that time, supervision was also a way of 'controlling' the teachers. The supervision primarily made them teach and do things that the superintendants wanted. It was thus a bureaucratic process, and, naturally, teachers were not very fond of the supervisors. This situation is best described by Arthur Blumberg (in: Pawlas \& Oliva, 2008), who characterizes the tension between teachers and supervisor as a "private cold war". While Tshabalala (2013) stated that the hierarchy and burdensome nature of certain supervisory approaches can cause resistance of teachers towards supervision. In contrast, Sharma and 
Kannan (2012) desrcibed instructional supervision as an activity towards leading efforts to improve teaching, observing in classrooms, and conferencing with teachers. They further argue instructional supervision as an activity to help teachers do their job better and improve the learning situation of children. In order to achieve the best outcomes out of supervision, the supervisor must seek for genuine cooperation and concern, positive and acceptable disposition among the teachers (Kotride \& Yunos, 2014) and motivate them towards improved process and outcomes (Ghavifekr \& Ibrahim, 2014).

\subsection{Supervision in the Malaysian Context}

Although supervision is compulsory for the principal to perform, there are many principals who do not fulfil this duty; some of them do it just to fulfil the task and ignore the main objective of supervision, which is to make teachers teach more effectively. Some studies have shown that a number of principals simply fail to practice their supervisory duties in a serious and regular manner (Sharma \& Kannan, 2012). These principals did not give any priority to supervision, and they did not show any interest in instructional practice. Moreover, they did not have any training regarding supervision (Foo \& Tan, 2001). In addition to this, many principals were not confident in conducting supervision. As a result, teachers were often sceptical and mistrustful, as regards the motives of the supervision. More often than not, they perceived it saw it as a 'fault finding activity' by the principal: teachers had the perception that supervision had a negative element that is to find the weakness and fault (Sharma \& Kannan, 2012).

Therefore, principals were not seen as being able to improve teachers' competencies in the classroom. Research by Othman and Mohamed (2003) has shown that the main objective of principal supervision in the classroom was merely of an administrative nature, apart from making sure that appropriate teaching and learning processes were carried out. Schools were said to carry out supervision as a preparation for observation by the school inspectorate or the state education department. The supervision process was, therefore, frequently treated as an evaluation practise, for which teachers were required to achieve certain predetermined standards. Those weaknesses in supervision practice - and the teachers' opposition to this kind of instructional supervision - can be seen to have a close relationship to supervision reliability. By contrast, teachers are more open towards supervision if they understand and participate actively in the supervision process. This view is supported by the findings of Foo and Tan (2001); and Sharma and Kannan (2012) who state that in a Malaysian context, teachers prefer collaborative supervision, whereby there is a much closer working environment between the supervisor and the supervisee. Also N. Yunus, J. Yunus, and Ishak (2012) argue the purpose of instructional supervision to boost morale and competencies of teachers.

\subsection{Supervisory Behaviors}

Glickman, Gordon, and Ross-Gordon (2007) have highlighted a variety of types of supervisory behaviours:

- The supervisor has full responsibility to make decisions on teaching improvement.

- Supervisor and teachers collaboratively find the best formula to improve teaching practice.

- Teachers are responsible to make their own decisions on teaching improvement through their own reflection. The supervisor functions to support and motivate only.

- Supervision must be based on teachers' development to improve teaching practice. That is why supervision should develop a teacher as a whole. This idea correlates with the findings of Glickman (2001), who argues that supervision must be based on developmental supervision.

Moreover, successful supervision involves three levels:

- The supervisors' attempts to diagnose teachers' conceptual level.

- The supervisors' effectiveness in using the three supervisory approaches of the developmental model (i.e.: directive, collaborative and non-directive)

- The teachers' and supervisors' evaluation of the approaches used most effectively

\subsection{The Problem}

Supervision is supposed to assist and develop teachers to improve the quality of their teaching and learning activities in the class so that these would become more effective. In order to achieve this, instructional supervision should be developmental. The question is: what is the best approach to be used by the administrator when conducting supervision in class? Teachers are normally against supervision, often despising it. The challenge of how to make supervision more 'teacher-friendly' is, indeed, substantial one. The researcher argues that a constructive start can be made, when the teachers are actually beginning to ask their supervisors to help them to 
improve their teaching practice. This means that, above all else, the perceptions of 'supervision' need to change. Both supervisor and teachers must go through a paradigm shift from looking at supervision as a way of 'controlling', to conceiving of it 'as a way to improve'. To make this change effectively, we first need to know more about the beliefs of the supervisors and teachers toward supervision. Previous studies have shown many contrasting findings regarding the effect of the demographic background affecting supervision. Both supervision practise and style are closely related to 'beliefs' in regard to the process. Wardi (2006) argues that most senior assistants in the scope of her study showed a predominantly 'directive' style of supervision. This research seeks to find out more about whether supervisory beliefs have any relation with the individual's background, with the position of the supervisor, supervising experience, teaching experience, academic qualification, age and gender and tries to respond to the following questions

1) What are the beliefs - in relation to 'supervision' - of supervisors and teachers?

2) Is there a relationship between those beliefs and the demographic background of the teachers (esp.: gender, position, teaching experience, supervision experience)?

\section{Method}

\subsection{Sample}

This study utilised survey, in order to explore the supervisory beliefs of teachers and supervisors. The sample school is one of the good schools in Malaysia. There are 75 teachers in the school. This study was conducted on 62 respondents as per sample size recommeded by Krejice and Morgan (1970) and demographic background of respondents is mentioned in Table 1.

In terms of gender, the highest number of respondents was female. There were $38(61.3 \%)$ female respondents and $24(38.7 \%)$ male respondents. On the basis of age-group it can be seen that the teachers who were above 40 years old dominate the number of teachers in this school, (37.1\%) of the respondents were under this age group. This was followed by respondents who are between 36 to 40 years old $(25.8 \%)$. Nearly a quarter $(24.2 \%)$ was below 30 years old and the smallest age group represented were those who were between 31 and 35 years old $(12.9 \%)$.

In terms of the respondents' functions in the school, $6.5 \%$ of them were administrators (principals and vice principals), $8.1 \%$ were heads of department, $14.5 \%$ were heads of panels(heads of specific subjects), and $71.0 \%$ were teachers.

The teaching experience and age were almost similar in proportion. Based on the teaching experience of the respondents the data showed that the majority $(43.5 \%)$ of the respondents had been teaching for more than 16 years. This was followed by a quarter $(25.8 \%)$ of the respondents who had 1 to 5 years teaching experience, $(17.7 \%)$ who had 11 to 15 years teaching experience and finally, $(12.9 \%)$ who had 6 to 10 years teaching experience.

There were only 2 options for supervising experience; either yes or no. In this context, 'supervising experience' meant that the teachers have been involved in supervising other teachers. In the sample, 29\% of the respondents indicated they had supervising experience, whereas $71 \%$ said they were without such experience. 
Table 1. Respondents demographic background

\begin{tabular}{|c|c|c|c|}
\hline Demographic & Respondents & Frequency & Percentage $(\%)$ \\
\hline \multirow{3}{*}{ Gender } & Male & 24 & 38.7 \\
\hline & Female & 38 & 61.3 \\
\hline & Total & 62 & 100.0 \\
\hline \multirow{5}{*}{ Age } & Below 30 years old & 15 & 24.2 \\
\hline & $31-35$ years & 8 & 12.9 \\
\hline & $36-40$ years & 16 & 25.8 \\
\hline & Above 40 years old & 23 & 37.1 \\
\hline & Total & 62 & 100.0 \\
\hline \multirow{5}{*}{ Position } & Administrator & 4 & 6.5 \\
\hline & Head of Department & 5 & 8.1 \\
\hline & Head of Panel & 9 & 14.5 \\
\hline & Teacher & 44 & 71.0 \\
\hline & Total & 62 & 100.0 \\
\hline \multirow{5}{*}{ Teaching Experience } & $1-5$ years & 16 & 25.8 \\
\hline & $6-10$ years & 8 & 12.9 \\
\hline & $11-15$ years & 11 & 17.7 \\
\hline & Above 16 years & 27 & 43.5 \\
\hline & Total & 62 & 100.0 \\
\hline \multirow{3}{*}{ Supervising Experience } & Yes & 18 & 29.0 \\
\hline & No & 44 & 71.0 \\
\hline & Total & 62 & 100 \\
\hline
\end{tabular}

\subsection{Data Collection Tool}

The instrument used for this research is adapted from the Supervisory Beliefs Inventory Instrument, formulated by Glickman and Tomashiro (1980). It was designed for supervisors and teachers, with the aim for these groups to be able to assess their own beliefs about supervision and professional development. The inventory assumes that supervisors and also teachers believe in all three approaches of supervision.The first part (see above) consisted of questions regarding the demographic background. The second part had 15 questions. Each question has 2 options and the subject was asked to select one answer only: A or B. There were 15 questions; multiplied by two options, there were thus 30 options altogether. The 30 options can be divided into 3 domains of preference, according to the above criteria: 'directive', 'collaborative', and 'non-directive'.

Based on the option chosen for each question we were able to identify the subject's overall supervisory beliefs, by employing the calculation that is further discussed under the rubric of 'data analysis', below. The objective of the instrument was to identify the subject demographic background and supervisory beliefs. In order to test the reliability of this instrument in a Malaysian context, it was administered over thirty teachers from different schools, to find a test-retest correlation. It was found that the correlation values of test-retest for Directive, Collaborative and Non-Directive are $.86, .79$, and .92 consecutively (at significant level $p<.05$ ). This means that the research instrument is suitable and reliable to obtain stable scores from other subjects that share the same characteristics with the subjects of this research.

\subsection{Analysis of Data}

Having been administered to the respondents, the instrument was subjected as follows to the following steps;

- Filling in of an inventory

- Calculation of supervisory beliefs, and:

- Statistical analysis

Step 1: Circle your answer from Part 11 of the inventory in the following columns. 
Table 2. Scoring key

\begin{tabular}{ccc}
\hline Column 1 & Column 2 & Column 3 \\
\hline 1B & 1A & \\
& $2 \mathrm{~B}$ & $2 \mathrm{~A}$ \\
3A & $3 \mathrm{~B}$ & \\
$4 \mathrm{~A}$ & & $4 \mathrm{~B}$ \\
& $5 \mathrm{~B}$ & $5 \mathrm{~A}$ \\
$6 \mathrm{~A}$ & & $6 \mathrm{~B}$ \\
& $7 \mathrm{~A}$ & $7 \mathrm{~B}$ \\
$8 \mathrm{~A}$ & & $8 \mathrm{~B}$ \\
$9 \mathrm{~A}$ & $9 \mathrm{~B}$ & \\
$10 \mathrm{~B}$ & & $10 \mathrm{~A}$ \\
$11 \mathrm{~A}$ & & $11 \mathrm{~B}$ \\
$12 \mathrm{~A}$ & $12 \mathrm{~B}$ & \\
& $13 \mathrm{~B}$ & $13 \mathrm{~A}$ \\
$14 \mathrm{~B}$ & $14 \mathrm{~A}$ & \\
& $15 \mathrm{~A}$ & $15 \mathrm{~B}$ \\
\hline
\end{tabular}

Step 2: Tally the number of circled items in each column and multiply by 6.7 .

2.1) Total response in column I

2.2) Total response in column II

2.3) Total response in column III

$$
\begin{aligned}
& \text { x } 6.7= \\
& \times 6.7= \\
& \times 6.7=
\end{aligned}
$$

This calculation is based on the calculation provided for the Supervisory Belief Inventory by Glickman and Tomashiro (1980). The total response from each column was multiplied by 6.7 , because there were 15 items and 6.7 represents $1 \%$ of 15 .

Step 3: Interpretation.

The product you obtained in step 2.1 is an approximate percentage of how often you take a directive approach to supervision, rather than either of the other two approaches. The product you obtained in step 2.2 is an approximate percentage of how often you take a collaborative approach and that in step 2.3 an approximate percentage of how often you take a non-directive approach.

Apart from calculation of each of the demographic details discussed above, the dependent variables were analyzed with relation to the choice of answers made by the respondent. The variables were: position, supervision experience, teaching experience, academic qualification, age and gender. Cross tabulation, Pearson Chi Square, and Cramer's V test were used to analyse the data.

\section{Results}

\subsection{The Supervisory Beliefs of the Respondents}

Table 3 shows the inclination of respondents towards the nature of directive and collaborative supervisory beliefs $(\mathrm{M}=1.61)$. More than half $(51.6 \%)$ of the respondents believe that supervision is directive and $(35.5 \%)$ believe it is collaborative. Only a very small number $(12.9 \%)$ believe that supervision is non-directive.

Table 3. Respondents supervisory beliefs

\begin{tabular}{lcc}
\hline Supervisory Beliefs' & Frequency & Percentage (\%) \\
\hline Directive & 32 & 51.6 \\
Collaborative & 22 & 35.5 \\
Non-Directive & 8 & 12.9 \\
Total & 62 & 100 \\
\hline
\end{tabular}

\subsection{Findings on the Basis of Gender}

From Table 4, it can be seen that supervisory beliefs did not differ according to gender $\left(X^{2} \quad(2, \mathrm{~N}=62)=.501\right.$, 
$\mathrm{p}>.05$ ). This indicates that supervisory beliefs of respondent were independent of gender. This is further supported by Cramer's V value of .090 , indicating that there was a weak correlation between gender and supervisory beliefs. Most of the respondents - both male and female - believe in more directive supervision. $50 \%$ of male respondents and $52.6 \%$ of female respondents shared the same belief. There are $8(33.3 \%)$ male respondents and $14(36.8 \%)$ female respondents evidenced collaborative beliefs. $4(16.7 \%)$ of the male respondents and $4(10.5 \%)$ of the female respondents adhered to non-directive beliefs.

Table 4. Relationship between gender and supervisory belief

\begin{tabular}{lcccc}
\hline Gender & N & Directive & Collaborative & Non-Directive \\
\hline Male & 24 & $12(50.0 \%)$ & $8(33.3 \%)$ & $4(16.7 \%)$ \\
Female & 38 & $20(52.6 \%)$ & $14(36.8 \%)$ & $4(10.5 \%)$ \\
\hline & Value & df & Asymp. Sig. (2-sided) & \\
Pearson Chi-Square & $.501^{\text {a }}$ & 2 & .779 & \\
\hline & Value & Approx. Sig. & & \\
Cramer's V & .090 & .779 & & \\
\hline
\end{tabular}

\subsection{Findings on the Basis of Age}

From Table 5 , it can be concluded that $\left(X^{2}(6, \mathrm{~N}=62)=.315, \mathrm{p}>.05\right)$ is not significant. This indicates that supervisory beliefs were found to be independent of their age. This is further supported by Cramer's V value of .239 , indicating that there is a weak correlation between age and supervisory belief. Based on Table 5, three age groups (below 30 years old, 31 to 35 years old and above 40 years old) exhibited the same value for directive and collaborative consecutively. For the age group below, $30(46.7 \%)$ of the respondents believed that supervision is directive, the same score is also observed for collaborative. Non-directive is the least popular (6.7\%) for this age group. For the 36 to 40 years old age group, the majority of respondents $(75.0 \%)$ believed supervision to be directive, while both collaborative and non-directive showed the same score $(12.5 \%)$. This confirms that supervisory beliefs were exhibited independently of age.

Table 5. Relationship between age and supervisory beliefs

\begin{tabular}{|c|c|c|c|c|}
\hline Age & $\mathrm{N}$ & Directive & Collaborative & Non-Directive \\
\hline Below 30 & 15 & $7(46.7 \%)$ & $7(46.7 \%)$ & $1(6.7 \%)$ \\
\hline $31-35$ & 8 & $3(37.5 \%)$ & $3(37.5 \%)$ & $2(25.0 \%)$ \\
\hline $36-40$ & 16 & $12(75.0 \%)$ & $2(12.5 \%)$ & $2(12.5 \%)$ \\
\hline \multirow[t]{2}{*}{ Above 40} & 23 & $10(43.5 \%)$ & $10(43.5 \%)$ & $3(13.0 \%)$ \\
\hline & Value & $\mathrm{df}$ & Asymp. Sig. (2-sided) & \\
\hline Pearson Chi-Square & $7.066^{\mathrm{a}}$ & 6 & .315 & \\
\hline Cramer's V & $\begin{array}{c}\text { Value } \\
.239\end{array}$ & $\begin{array}{c}\text { Approx. Sig. } \\
.315\end{array}$ & & \\
\hline
\end{tabular}

\subsection{Findings on the Basis of Position}

From Table 6, it can be seen that supervisory beliefs' did not differ by position $\left(X^{2}(4, \mathrm{~N}=62)=.819, \mathrm{p}>.05\right)$. This indicates that supervisory belief of the individual respondent is independent of their position. This is further supported by Cramer's $\mathrm{V}$ value of .153 , indicating that there is a weak correlation between position and supervisory belief. Based on Table 6, the score for a directive supervisory belief is high for each of the position:

- $\quad$ Administrator $(50 \%)$

- Head of Department (40\%)

- Head of Panel (55.6\%)

- $\quad$ Teacher $(52.3 \%)$.

This was followed by the findings pertaining to collaborative belief:

- Administrators (50\%)

- Heads of Department (60\%) 
- $\quad$ Head of Panel (33.3\%)

- $\quad$ Teacher $(31.8 \%)$.

It can be observed that, in the case of head of department, the percentage for collaborative is higher than directive. However, this may be due to the small number of respondents in this group, and the difference is actually 1 in number. Non-directive belief was not popular among the respondents, with the findings as follows:

- $\quad$ Administrators $(0 \%)$

- Head of Department ( $0 \%)$

- Head of Panel (11.1\%)

- $\quad$ Teacher (15.9\%).

None of the positions showed a distinctive preference for a specific supervisory belief. This confirms that supervisory belief is independent of position.

Table 6. Relationship between position and supervisory beliefs

\begin{tabular}{lcccc}
\hline Position & $\mathrm{N}$ & Directive & Collaborative & Non-Directive \\
\hline Administrator & 4 & $2(50.0 \%)$ & $2(50.0 \%)$ & - \\
Head of Department & 5 & $2(40.0 \%)$ & $3(60.0 \%)$ & - \\
Head of Panel & 9 & $5(55.6 \%)$ & $3(33.3 \%)$ & $1(11.1 \%)$ \\
Teacher & 44 & $23(52.3 \%)$ & $14(31.8 \%)$ & $7(15.9 \%)$ \\
\hline & Value & df & Asymp. Sig. (2-sided) & \\
Pearson Chi-Square & $2.918^{\text {a }}$ & 6 & .819 & \\
\hline & Value & Approx. Sig. & \\
Cramer's V & .153 & .819 & \\
\hline
\end{tabular}

\subsection{Findings on the Basis of Teaching Experience}

From table 7, it becomes evident that supervisory beliefs' did not differ by teaching experience $\left(X^{2}(6, \mathrm{~N}=62)\right.$ $=.088, \mathrm{p}>.05$ ). This indicates that supervisory belief of the respondents was independent of their teaching experience. This is further supported by Cramer's V value of .298, indicating that there is a weak correlation between teaching experience and supervisory belief. Experience normally plays a significant role in connection with viewing an individual at work, and doing things for them. However, from the results reported here, there was no significant difference in the choices made by the respondents from each group. Table 4.7, shows that the respondents with 11 to 15 years of teaching experience were inclined more towards directive supervisory belief (72.7\%). Other groups the spread did not differ far from the main score whereby directive got the majority followed by collaborative; non-directive was the least preferred.

Table 7. Relationship between teaching experience and supervisory beliefs

\begin{tabular}{|c|c|c|c|c|}
\hline Teaching Experience (years) & $\mathrm{N}$ & Directive & Collaborative & Non-Directive \\
\hline $1-5$ & 16 & $8(50 \%)$ & $8(50 \%)$ & - \\
\hline $6-10$ & 8 & $3(37.5)$ & $2(25 \%)$ & $3(37.5 \%)$ \\
\hline $11-15$ & 11 & $8(72.7 \%)$ & $1(9.1 \%)$ & $2(18.2 \%)$ \\
\hline Above 16 & 27 & $32(51.6 \%)$ & $22(35.5 \%)$ & $8(12.9 \%)$ \\
\hline & Value & $\mathrm{df}$ & Asymp. Sig. (2-sided) & \\
\hline Pearson Chi-Square & $11.018^{\mathrm{a}}$ & 6 & .088 & \\
\hline Cramer's V & $\begin{array}{l}\text { Value } \\
.298\end{array}$ & $\begin{array}{c}\text { Approx. Sig. } \\
.088\end{array}$ & & \\
\hline
\end{tabular}

\section{Discussion}

Based on Table 3, the most dominant supervisory belief in this school was in the directive category. $51.6 \%$ of the teachers in this study evidenced this particular variant of supervisory belief. This is not unusual. It can be expected as previous studies show that teachers generally perceive supervision as 'directive' and 'formal' meant to 'evaluate' - and not to 'improve' - them. Ghazali, Othman and Mohamed (2003) posit that teachers 
perceive supervision as a practice conducted with a largely 'prepared' schedule, and that there was the requirement that every teacher had to be subjected to supervision twice a year.

Supervision was perceived as predominantly 'negative' by the teachers included in this study. They saw 'supervision' as something that 'has no effect' on them, since there was no feedback after the observation in their classroom. Lani (2002), Sharma and Kannan (2012) states that there are teachers who believe that 'supervision' is a way to 'evaluate' and 'penalise' the teachers. The same result was confirmed by this study. Many teachers looked at 'supervision' as mainly 'directive'. This is owing to many reasons, and partly due to a lack of knowledge and past experience with supervision. Based on Table 3, the score for collaborative belief was 22 (35.5\%). Consequently, this particular school should be looking into this type of supervision in the future.

Compared to directive supervision, collaborative supervision is supposed to be more about developing teachers' potential. It is about working together to improve the teachers' standards. This is attractive and may be the reason for the collaborative belief to be in second place here. Another important aspect of this supervision, which renders it better than a directive style, is the fact that teachers are more willing to change, when the change comes from them and is not directed or imposed from elsewhere. This type of supervision can ensure improvement in the future.These findings are in accordance with studies by Sharma and Kannan (2012), Kotride and Yunos (2014), and Ghavifekr and Ibrahim (2014) .

From Table 4, it can be seen that Cramer's V test score of 0.09 , the relation is weak between gender and supervisory belief. Both male and female score a high percentage for directive: $50 \%$ for male and $52.6 \%$ for female respondents. This is followed by collaborative $(33.3 \%)$ for male and $(36.8 \%)$ for female respondents. Finally, for non-directive the score is $16.7 \%$ for male and (10.5\%) for female respondents. We can see a pattern emerging here, where gender does not appear to have been a significant factor. The most preferred supervisory belief for both genders is directive. It can be safely said that there is almost no relationship between gender and supervisory beliefs.

Wardi (2006), in his study of perception towards supervision, stated that female and male teachers perceive supervision differently. According to this, female teachers prefer directive supervision while the males prefer non-directive supervision. However, this study did not show that there is any difference between male and female teachers in this respect. Many of the respondents preferred directive style, followed by collaborative. Non-directive was the least popular belief exhibited here.

From Table 5 it can be seen that Cramer's V score of .239 for the correlation between age and supervisor beliefs indicates that the relation is very weak. There seemed to be no link between supervisory beliefs and age. There were 4 age groups in this study; below 30 years old, 31-34 years old, 36-40 years old, and above 40 years old. The result showed almost the same pattern for all age groups, except for the $36-40$ years olds. With the exception of the 36-40 years old group all the other age group in this study reached the same score for directive and collaborative supervisory belief, exhibiting a very low score for non-directive preferences.

For the 36-40 age range, the majority of the respondents under this age chose directive at $75 \%$ leaving only $12.5 \%$ each for collaborative and non-directive. This finding shows differences from the findings of Wardi (2006), who identifies age influences on the leadership styles and behaviour of the managers. These findings suggest that younger and older managers have different profiles in their consultative and participative leadership styles. Older managers consulted more widely and favour more participation, in comparison with younger managers. However the two groups of managers both practice directive and delegating leadership styles, at about the same degree. From Table 6 it can be concluded that a Cramer's score of .153 means the relationship between position and supervisory belief is very weak. At the school in question, positions were divided into 4 groups: administrators, heads of department, heads of panel and teachers. For the administrators, the results were sub-divided into 2 groups, $50 \%$ directive and 50\% collaborative. For the head of panel and teachers the percentage spread are almost identical; around $50 \%$ for directive, around $30 \%$ for collaborative and more or less $10 \%$ for non-directive. The result again shows that there is no relation between position and supervisory belief. Based on previous studies there is evidence which shows that administrators prefer a more directive style in their leadership. Ismail (2000), in her study found that the most dominant style of leadership used by principals is directive style. These findings are supported by research undertaken by Wardi (2006), with regard to teachers: those with supervision experience were found to lean more towards a more directive style of supervision. This shows that many of the supervisors were 'autocratic', believing that supervision is a way to direct and control their subordinates. By contrast, Avery (2001) expresses a different opinion. He finds that supervisors and managers prefer a supporting style, rather than an overly directing style. In his research, $50 \%$ of the respondents used more than one style depending on the situation. According to Wardi (2006), there was no significance 
difference in instructional leadership styles among the Senior Assistants. Wardi also noted that the positions of senior teachers - whether they are senior assistants for curriculum, students affairs or co-curricular - were of no significance for their leadership styles. The result of this study did not show any supervisory belief preference based on position. As the case with gender and age, position seems to have no impact on supervisory beliefs.

Our results also show that supervisory belief was independent of career and work position. Looking at Table 7, a Cramer's V value of .298 can be observed for the relation between teaching experience and supervisory beliefs. This, again, is very weak. It indicates that teaching experience is not a factor for supervisory belief. The respondents were divided into 5 groups based on their years of teaching experience; 1-5 years, 6-10 years, 11-15 years and above 16 years. From the score gathered there is no significant difference between each group. The score did not show any particular preference for each group. Only in the cases of those who had 11-15 years of experience, there were some significant differences: $72.7 \%$ in this group fell into the category of directive supervisory belief. From these results, it is clear that the directive style was the most preferred belief among all age groups. Moreover, Wardi (2006) states that teachers who are below 30 years old prefer to use strategy and teaching methods which have been proven effective and they prefer the supervisor to guide them. This shows that teachers who can be considered 'novice' or 'young' prefer directive supervision. Senior teachers, on the other hand, prefer to discuss and have the freedom to teach their class their own way. The result of this study differs from Wardi (2006), because there is no indication that age has any effect on supervisory belief. Those who have 1-5 years of experience, and those who have more years of experience seem, to exhibit no significant attitudinal differences when it comes to supervisory beliefs. The majority in each group expressed a preference for a more directive supervisory belief. We do not see this as unusual, since, as a rule, teachers are not exposed to new knowledge about supervision. The word supervision continues to connote something negative to them.

\section{Conclusion}

Throughout this study directive supervision was found to be the dominant practice. This should be viewed with some concern. Since directive supervision is frequently seen to be resulting in 'fault-finding', and is not perceived as contributing to the teachers' professional development it should be avoided. The results of our research suggest that a more collaborative approach should be practised in order to make supervision more meaningful.

\section{Suggestion}

Since this study involves perceptions, inorder to generate more prepositions a mixed mode research approach is desired to investigate the reasons for only two preferred methods.Also future studies should be conducted on bigger sample to generalize the issues pertaining to instructional supervision in Malaysian schools and contribute towards literature in the field.

\section{References}

Avery, G. C. (2001). Situational leadership preferrences in Australia: congruity, flexibility and effectiveness. Leadership and Organizational Development Journal, 22(1), 11-21. https://doi.org/10.1108/01437730110380183

Beach, D. M., \& Reinhartz, J. (2000). Supervisory Leadership: Focus on Instruction. Pearson, Massachusetts.

Foo, S. F., \& Tan, K. N (2000). Kepimpinan Pengajaran Pengetua/Guru Besar dan Kepuasan Guru. Jurnal Institut Aminuddin Baki, Kementerian Pendidikan Malaysia, 2, 36-42.

Ghavifekr, S., \& Ibrahim, M. S. (2014). Head of Departments'instructional supervisory role and taechers' job performance:teachers' perception. Asian Journal of Social Sciences and Management Studies, 1(2), 45-56.

Ghazali, M. A., Othman, N., \& Mohamed, N. (2003). Penyeliaan: Kajian Ke Atas Tiga Buah Sekolah Menengah. Jurnal Pemimpin Institut Pengetua. Universiti Malaya, 3, 36-48.

Glickman, C. D. (2001). Developmental Supervision. Washington D.C. ASCD.

Glickman, C. D., \& Tamashiro, R. T. (1980). Determining One's Beliefs Regarding Teacher Supervision. NASSP Bulletin, 64(440), 74-81. https://doi.org/10.1177/019263658006444019

Glickman, C. D., Gordon, S. P., \& Ross-Gordon, J. M. (1997). Supervision of Instruction: A Developmental Approach (4th ed.). Boston, Allyn Bacon.

Glickman, C. D., Gordon, S. P., \& Ross-Gordon, J. M. (2004). Supervision and Instructional Leadership: A developmental Approach (6th ed.). Pearson, Massachusetts.

Glickman, C. D., Gordon, S. P., \& Ross-Gordon, J. M. (2007). Supervision and instructional Leadership (7th ed.) 
Boston: Allyn and Bacon.

Kotirde, I. Y., \&Yunos, J. B. M. (2014). The supervisors' role for improving the quality of teaching and learning in Nigeria secondary school educational system. International Journal of Eduaction \& Research, 2(8), 53-60.

Krejcie, R. V., \& Morgan, D. W. (1970). Determining sample size for research activities. Educational and Psychological Measurement, 30, 607-610. https://doi.org/10.1177/001316447003000308

Lani,S. Z. (2002). Anjakan Paradigama Dalam Penyeliaan Pengajaran Di Sekolah-Sekolah. Jurnal Pemimpin Institut Pengetua. Universiti Malaya, Kuala Lumpur,

Pawlas, G. E., Oliva, P. F. (2008). Supervision For Today's Schools (8th ed.). John Wiley \& Son Inc., New Jersey.

Sergiovanni, T. J., \& Starratt, R. J. (2006). Supervision: A Redefinition. McGraw-Hill.

Sharma, S., \& Kannan, S. (2012). Instructional supervision a tool for improvement or weapon for punishment. Research Journal of Social Sciences \& Management, 2, 829-835.

Sullivan, S., \& Glanz, J. (2000). Supervision That Improves Teaching. Corwin Press, California

Tshbalala, T. (2013). Teachers'perception towards classroom instructional supervision: A case study of Nkayi district in Zimbabave. International Journal of Social Science and Education, 4(1), 25-32.

Wardi, H. (2006). Kepimpinan Pedagogi Penolong-Penolong Kanan Sekolah Menengah Daerah Gombak, Selangor. Tesis Sarjana, Institut Pengajian Kepengetuaan. Universiti Malaya Kuala Lumpur

Yunus, N., Yunus, J., \& Ishak, S. (2012). The school principals' role in teaching supervision in selected schools in Perak, Malaysia. Asian Journal of Management and Business Sciences, 1(2), 52-55.

Zakaria, H. (2004). Pemahaman Guru Terhadap Pencerapan di Sebuah Sekolah Di Daerah Kota Bharu, Kelantan. Tesis Sarjana, Institut Pengajian Kepengetuaan. Universiti Malaya Kuala Lumpur.

\section{Copyrights}

Copyright for this article is retained by the author(s), with first publication rights granted to the journal.

This is an open-access article distributed under the terms and conditions of the Creative Commons Attribution license (http://creativecommons.org/licenses/by/4.0/). 